\title{
DETERMINANTS OF EFFECTIVE TAX RATES IN TURKEY
}

\author{
TÜRKIYY'DE EFEKTIF VERGİ ORANLARININ BELİRLEYİCİLERI
}

Çağrı AKSOY HAZIR*

\begin{abstract}
This study aims to analyze the determinants of effective tax rates by Turkish public listed companies. It is motivated by the lack of studies on firms' tax reporting behaviors in Turkey. It focuses on Turkish public listed companies (excluding banking and insurance sectors) between 2007-2016 and data were extracted from the financial statements of firms in respect of the variables. The study establishes the relationship between ETRs and firm specific characteristics of size, leverage, asset mix and profitability. The application of panel data estimation procedures finds that the tax burden is determined by the characteristics of firm size, leverage and capital intensity of each company. The contribution of this paper is two-fold. Firstly, it is the first study in the context of Turkish public listed companies and their ETRs, secondly it gives information to corporate managers, investors and academics about tax burden of Turkish public listed companies.
\end{abstract}

Keywords: Effective tax rate, tax burden, Turkey

JEL Classification: H25, M40, M41

Öz

Bu çalışmada, halka açı Türk şirketlerinde efektif vergi oranlarının belirleyicilerinin analiz edilmesi amaçlanmıştır. Çalışma, Türkiye’deki şirketlerin vergi raporlama davranışlarının daha önce çalışılmamış olmasına dayanılarak ortaya konmuştur. Çalışmada 2007-2016 aralığında Türkiye'de borsaya kote olan finansal olmayan şirketlere odaklanılmış ve değişkenler dikkate alınarak ilgili veriler söz konusu şirketlerin finansal raporlarından elde edilmiştir. Bu çalışmada efektif vergi oranları ve şirketlere özgü nitelikler olan şirket büyüklüğü, kaldıraç, varlık yapısı ve karlılık arasındaki ilişki ortaya konmuştur. Panel veri analizinin uygulanması ise vergi yükünün şirket büyüklüğü, kaldıraç ve sermaye yoğunluğu ile ilişkili olduğu tespit edilmiştir. Bu çalışmanın iki açıdan katkısı mevcuttur. İlk olarak halka açık Türk şirketleri ve efektif vergi oranları kapsamındaki ilk çalışmadır ve ikincil olarak çalışma halka açık Türk şirketlerinin vergi yüküne ilişkin kurumsal yöneticilere, yatırımcılara ve akademisyenlere bilgi sunmaktadır.

Anahtar Kelimeler: Efektif vergi oranı, vergi yükü, Türkiye JEL Classification: H25, M40, M41

* PhD, Marmara University, Faculty of Business Administration, cagri.aksoy@marmara.edu.tr, ORCID: 0000-0003-1172-1412.

To cite this article: Aksoy Hazır, Ç. (2019). Determinants of Effective Tax Rates in Turkey. Journal of Research in Business, 4(1), 35-45. DOI: 10.23892/JRB.2019453293 


\section{Introduction}

Tax system of a country is used as a mechanism to raise country revenue, to encourage economic growth, to stabilize the economy and to redistribute the wealth. It is not only a fundamental tool to fiscal system, it has also impact on companies' decisions, such as financing and investment decisions, dividend policy or accounting choices. Therefore it has been the subject of many previous studies from various perspectives. The rate of corporate income tax is called statutory tax rate, which does not provide an entire measure of the actual tax burden of companies. Statutory tax rate leaves aside the other features of tax system such as deferral taxes, tax base or exemptions. To provide a full picture of effective corporate taxation, effective tax rates of companies should be taken into consideration.

Companies should be aware of their effective tax rates (ETRs), because taking into consideration of ETRs gives companies the possibility of summarizing in one statistic the cumulative effect of various tax incentives (Gupta\&Newberry, 1997). Since ETRs can reflect a firms' actual tax burden, there has been several studies, which have been carried out on measurement of ETR and its firm specific characteristics. Given the focus of the determinants of ETRs, previous studies do not show a clear relation between ETRs and firm specific characteristics and also these studies have been conducted generally in developed countries.

The motivation of this study is to provide evidence on the explanatory factors of ETRs caused by corporate income taxation for public listed companies in Turkey. This subject is relevant, because no prior studies have been conducted in Turkey. In Turkey, corporations are taxed at a rate of $20 \%$ and this statutory tax rate applies to all types of corporations. In general, ETR is of great interest to public and policy makers alike, however it is also relevant for corporate managers and investors, because it can also be used as a tool to identify the characteristics of firms with higher and lower tax burdens. This study provides evidence on the firm specific determinants of ETRs for Turkish listed companies. It contributes to previous literature in several ways. First, the major contribution is dealing with effective taxation in Turkey based on firm-level data for the period 2007-2016 and secondly, this study yielded contradictory results regarding the variables explaining ETRs. This study also attempts to contribute to the literature through examining the determinants of ETR in an emerging market.

The remainder of the study is organized as follows. In Section 2 an overview of the previous literature related to the study is presented and hypothesis are developed. Section 3 dedicated to the research design. Regression results are showed and discussed in Section 5, then in final section the most relevant conclusions are presented.

\section{Literature Review and Hypothesis}

There are many studies that explore what determines a firm's effective tax rates and most of the existing studies have been carried out for US companies, EU companies and Australian companies, whereas few studies have analyzed companies in emerging markets. Previous studies report differing results for the determinants of effective tax rates and regarding the results, it should be noted that ETRs' determinants are mainly firm specific characteristics such as firm size, leverage, asset mix 
and profitability. The empirical results are inconclusive because they differ from country to country, region to region and even within a single country.

Firm Size: One of the main factors advanced in the literature to explain tax burden of a company is firm size. This is justified by two contradictory arguments. On one hand the relationship between ETRs and firm size will be positive under the political cost hypothesis, where the higher visibility of larger and more successful firms causes them to be victims of greater regulatory actions and wealth transfers (Watts\&Zimmerman, 1986). Zimmerman (1983) suggest that firms with larger size may have fewer preferences available than firms with smaller size. Omar et. al. (1993) supports this notion regarding the association between firm size and ETRs are not affected by the choice of effective tax rate measure. Authors such as Plesko (2003) and Noor et.al. (2010) demonstrate also a positive relationship between firm size and ETRs. Conversely, Porcano (1986) observed an inversed relationship between firm size and ETRs which is called political power hypothesis. The political power hypothesis predicts an inverse association, because large companies have more resources for political lobbying and tax planning (Porcano 1986). In line with the political power hypothesis, Kim\&Limpaphayom (1998), Derashid\&Zhang (2003), Harris\&Feeny (2003), Janssen (2005), Richardson\&Lanis (2007), Chen et.al. (2010) and Fernández-Rodríguez\&Martínez-Arias (2014) observe also a negative relationship between firm size and ETRs. However, Stickney\&McGee (1982), Shevlin\&Porter (1992), Gupta\&Newberry (1997), Feeny et.al. (2006) and Liu\&Cao (2007) observed an inconclusive relationship between firm size and ETRs.

All of these studies used different empirical approaches, including ETR measurement, time periods or sample selection, therefore according to theoretical perspective, any type of association can be expected between firm size and ETRs. First hypothesis to be tested is as follows:

\section{H1: There is a relationship between firm size and ETRs.}

Leverage: In previous studies, tax incentives have been modelled as a function of a firm's financing decisions. According to Gupta\&Newberry (1997), firm's financing decision could affect ETRs, because tax status allow different tax treatment to the capital structure decisions of firms. Since the interest expenses are tax deductible, a firm's capital structure can have impact on ETRs. Studies by Stickney\&McGee (1982), Derashid\&Zhang (2003), Liu\&Cao (2007), Richardson\&Lanis (2007) and Noor et.al. (2010) find that highly leveraged firms are subject to a smaller tax burden than those that are less leveraged firms. On the contrary, Harris\&Feeny (2003), Janssen (2005) and Chen et al. (2010) observe a positive relationship between leverage and ETRs, they report that highly leveraged firms might lead to finance themselves by debt to reduce the ETRs. Alternatively, it may be possible to find a nonlinear relationship between leverage and ETRs. In line with this argument FernándezRodríguez\&Martínez-Arias (2011) and Delgado et.al. (2012) find that the it is positive up to a certain level of debt, causing a variation in the association between leverage and ETRs. Consistent with the previous literature, it can be pointed to a relationship between leverage and ETRs.

H2: There is a relationship between leverage and ETRs. 
Asset Mix: The asset mix of a firm may have impact on its ETR, in particular through the fixed assets allowing firms to subtract the depreciation expenses in all tax regimes. Therefore, firms the greater proportion of fixed assets should have lower ETRs. In accordance with this argument Stickney\&McGee (1982), Gupta\&Newberry (1997), Derashid\&Zhang (2003), Janssen (2005), Richardon\&Lanis (2007), Noor et.al. (2010) and Chen et.al. (2010) all find a direct relationship between capital intensity and ETRs. Other studies on the other hand (Harris\&Feeny 2003; Liu\&Cao 2007) do not find a significant association between capital intensity and tax burden of a company. Finally, Fernández-Rodríguez\&Martínez-Arias (2011) and Delgado et. al. (2012) show that a nonlinear relationship between capital intensity and ETRs exists.

From the perspectives of asset mix, the use of stocks for carrying out the firm's activity may have impact on a firm's tax burden. Regarding this perspective, investment in inventories is considered as a possible way of using funds to buy fixed assets, limiting the chance of reducing ETRs (FernándezRodríguez\&Martínez-Arias 2012). The relation between inventory intensity and ETRs has been empirically tested in previous studies (Gupta\&Newberry 1997; Richardson\&Lanis 2007; FernándezRodríguez\&Martínez-Arias 2011; Fernández-Rodríguez\&Martínez-Arias 2014). FernándezRodríguez\&Martínez-Arias (2014) found a relationship between inventory intensity and ETRs, controversially Derashid\&Zang (2003) do not find a significant relationship between inventory intensity and ETRs. In view of these points, the hypotheses are as follows;

H3: There is a relationship between capital intensity and ETRs.

H4: There is a relationship between inventory intensity and ETRs.

Profitability: Various empirical studies have shown that profitability is also a determinant of a firm's tax burden (Stickney\&McGee 1982; Gupta\&Newberry 1997; Liu\&Cao 2007; Richardson\&Lanis 2007; Fernández-Rodríguez\&Martínez-Arias 2011). As is usual in those studies, more profitable companies are more likely to have higher level of ETRs. However, Derashid\&Zhang (2003) and Noor et.al. (2008), whose studies focused on Malaysian companies, find an inverse relationship between profitability and ETRs. They concluded that this relationship is a consequence of the tax incentives provided by the government. Following the previous studies, the hypothesis is as follows;

H5: There is a relationship between profitability and ETRs.

\section{Research Design}

\subsection{Sample and Data}

For this study, the data was obtained from Public Disclosure Platform, which is the leading financial information provider in Turkey. The data corresponds to public listed companies in Turkey (excluding banking and insurance sectors) during the period 2007 - 2016, comprising a total of 2640 firm-year observations. 
As is usual in this type of study, the data filtering is necessary as ETRs do not have economic meaning whenever its denominator, which is the income, is zero or negative (Wilkie\&Limberg 1993). To facilitate the study, also companies having negative tax expense which produced negative ETRs are recorded as 0 and companies with an ETR above $100 \%$ are recorded as 1.

\subsection{Dependent and Independent Variables}

In examining the determinants of ETRs of public listed companies in Turkey, the dependent variable is represented by effective tax rate (ETR). In previous studies there has been various methods for measuring ETRs, of which commonly used are those based on financial data. Different ETR measures results from different definitions of numerator and denominator, where the numerator is the measure of a firm's tax liability and the denominator is the measure of its income (Plesko 2003). In the denominator, Stickney\&McGee (1982) uses pre-tax income adjusted for the effect of timing differences and according to their approach the numerator should include the all taxes actually payable for the year to all governmental units in order to obtain a more consequential signal of the tax burden (Gupta\&Newberry 1997). According to Zimmerman (1983) operating cash flow is the best measure to use in the denomination, since it eliminates the effects of different accounting treatments to income. He defines his numerator as income taxes, which are computed as total income tax expense, less the change in deferred taxes and deferred investment tax credits. Porcano (1986) states that the numerator should include current taxes and he uses pretax book income adjusted income or losses associated with extraordinary items and discontinued operations as denominator. Shevlin (1987) uses essentially the same formula as Stickney\&McGee (1982), except his numerator is total tax expense less the change in the deferred tax liability. Since there are several ways to measure ETR, the ETR in this study, which is based on Porcano (1986)'s approach, measured as the ratio of real tax expense (tax expenses - deferred tax expenses) to earnings before interest and taxes (EBIT). Since EBIT represents firm earnings which results from the operation of the resource controlled by firms before paying to creditors, shareholders and government (Liu\&Cao 2007), EBIT is used in this study as the denominator of ETR.

The independent variables used in this study are as follows:

- Size: Firms size (SIZE) is measured as the natural logarithm of firm's total assets. Due to inconsistent results and theoretical perspectives of previous studies any type of relation between firm size ETRs can be expected.

- Leverage: Following the most of the prior studies leverage (LEV) is defined as the ratio of total debt to total assets. According to the deductibility of interest, the association of leverage and ETR can be negative.

- Asset Mix: Two independent variables are included in the study to proxy for firm's asset mix; capital intensity (CAPINT) and inventory intensity (INVINT). Capital intensity is measured as fixed assets divided by total assets and inventory intensity measured as inventory divided by total assets. In line with most previous studies, a negative relation between capital intensity and 
ETRs can be expected and a positive relationship between inventory intensity and ETRs can be observed.

- Profitability: Since ETRs can change simply due to changes in book income, the most suitable measure is return on assets (ROA), defined as the ratio of pre-tax income divided by total assets. Due to the previous results an increase in ROA can lead to an increase in ETRs.

\subsection{Regression Model}

Panel data multivariate model, that combines the advantages of cross-sectional model and time series model, is used to test the relationships regarding determinants of ETR. In this study regression analysis was carried out using fixed effects model (FEM), random effects model (REM) and pooled ordinary least squares (pooled OLS). The model specification is as follows:

$E T R_{i t}=\mathrm{b}_{0}+\mathrm{b}_{1} S I Z E_{i t}+\mathrm{b}_{2} L E V_{i t}+\mathrm{b}_{3} C A P I N T_{i t}+\mathrm{b}_{4} I N V I N T_{i t}+\mathrm{b}_{5} R O A_{i t}+\mathrm{e}_{i t}$.

Where i denotes the company, $\mathrm{t}$ denotes the years from 2007 - 2016 and $\mathrm{b}$ is the coefficient of regression and $\mathrm{e}$ is the error term. To compare the efficiency of models, the statistical tests like LR test, LM test and Hausman test have been used.

\section{Results}

\subsection{Descriptive Statistics}

The descriptive statistics for the variables are shown in Table 1 and it gives the mean, standard deviation, median, minimum and maximum of dependent and independent variables from 2007 to 2016.

Table 1: Descriptive Statistics of All Variables

\begin{tabular}{llllll}
\hline Variable & Mean & Standard Deviation & Maximum & Minimum & Median \\
\hline ETR & 0.1477 & 0.2048 & 1.0000 & 0.0000 & 0.0982 \\
SIZE & 8.4157 & 0.8692 & 11.4889 & 5.7230 & 8.4051 \\
LEV & 0.4706 & 0.4357 & 8.6743 & 0.0003 & 0.4465 \\
CAPINT & 0.2586 & 0.2266 & 0.9869 & 0.0000 & 0.2296 \\
INVINT & 0.1235 & 0.1409 & 0.9199 & 0.0000 & 0.0887 \\
ROA & 0.0477 & 0.3163 & 8.8308 & -7.1228 & 0.0444 \\
\hline
\end{tabular}

As shown in Table 1, the average ETR is about 15 percent, it has a median of 9,8 percent. For the independent variables, size has a mean of 8.41 and a median of 8.40 , leverage has a mean of 0.47 and a median of 0.45 , capital intensity has a mean of 0.26 and a median of 0.23 , inventory intensity has 
a mean of 0.12 and a median of 0.09 and ROA has a mean of 0.05 and a median of 0.04 . Further, the results indicate that the level of consistency between means and medians for all variables is reasonable.

The descriptive statistics indicate that highest ETR is in 2007 about 16 percent and interestingly global financial crisis in 2008/2009 is not likely to have had significant effects on ETRs of public listed companies in Turkey. Table 2 gives the descriptive statistics of ETRs during 10 years of the research period.

Table 2: Descriptive Statistics of Dependent Variable

\begin{tabular}{llllll}
\hline Year & Mean & Standard Deviation & Maximum & Minimum & Median \\
\hline 2007 & 0.1615 & 0.1949 & 1.0000 & 0.0000 & 0.1498 \\
2008 & 0.1443 & 0.2262 & 1.0000 & 0.0000 & 0.0391 \\
2009 & 0.1452 & 0.2024 & 1.0000 & 0.0000 & 0.0926 \\
2010 & 0.1432 & 0.1917 & 1.0000 & 0.0000 & 0.1011 \\
2011 & 0.1331 & 0.1847 & 1.0000 & 0.0000 & 0.0905 \\
2012 & 0.1521 & 0.1918 & 1.0000 & 0.0000 & 0.1243 \\
2013 & 0.1443 & 0.2114 & 1.0000 & 0.0000 & 0.0796 \\
2014 & 0.1471 & 0.2051 & 1.0000 & 0.0000 & 0.0982 \\
2015 & 0.1467 & 0.2122 & 1.0000 & 0.0000 & 0.0938 \\
2016 & 0.1592 & 0.2255 & 1.0000 & 0.0000 & 0.0920 \\
\hline
\end{tabular}

Pearson correlation coefficients for dependent and independent variables are reported in Table 3. According to the correlation matrix; ETR and firm size have positive and significant correlation, supporting political cost theory. Correlation matrix indicates that capital structure of companies in Turkey have a negative but insignificant relationship. However, capital intensive firms appear to have higher ETRs. The largest correlation among independent variables is only 0.164 for the correlation between firm size and leverage.

Table 3: Correlation Matrix of Variables

\begin{tabular}{lllllll}
\hline & ETR & SIZE & LEV & CAPINT & INVINT & ROA \\
\hline ETR & 1.0000 & & & & & \\
SIZE & $0.1079^{* *}$ & 1.0000 & & & & \\
LEV & -0.0235 & $0.1648^{* *}$ & 1.0000 & & & \\
CAPINT & $0.1304^{* *}$ & $0.1455^{* *}$ & $0.1327^{* *}$ & 1.0000 & & \\
INVINT & 0.0154 & $-0.0390^{* *}$ & $0.1047^{* *}$ & 0.0125 & 1.0000 & \\
ROA & 0.0047 & $0.0799^{* *}$ & $-0.0769^{* *}$ & 0.0049 & 0.0196 & 1.0000 \\
\hline
\end{tabular}

$* *$ denotes statistical significance at the $5 \%$ levels, respectively. 
Moreover, it appears that larger firms are more profitable, are associated with high leverage and high capital intensity, but they are less inventory intensive.

\subsection{Regression Results}

For testing the null hypothesis of individual-specific effects between FEM and pooled OLS, LR test is used and LR test value indicated that FEM is more efficient than pooled OLS. For the comparison of REM and pooled OLS, Breusch-Pagan Lagrange Multiplier (LM) is used and the statistics showed that REM performed better than pooled OLS. In order to choose between REM and FEM, the Hausman test is used. The Hausman test did not reject the null hypothesis, so the preferred model is random effects model. (Hausman chi2 $=1.75$ ). Table 4 summarizes the results of random effects regression for the research model.

Table 4: Random Effects Model Regression Results

\begin{tabular}{llll}
\hline Variable & Predicted Sign & Coefficient & Z-value \\
\hline SIZE & $?$ & 0.0258 & $3.88^{* *}$ \\
LEV & - & -0.0306 & $-2.51^{* *}$ \\
CAPINT & - & 0.1105 & $4.72^{\star *}$ \\
INVINT & + & 0.0470 & 1.25 \\
ROA & + & -0.0088 & -0.72 \\
& & & \\
Adjusted R-Squared & 0,093 & & \\
\hline
\end{tabular}

** denotes statistical significance at the $5 \%$ level (two-tailed).

Regression model is significant with adjusted $\mathrm{R}^{2}$ of 9 percent for effective tax rates. The coefficient of size is positive and significant, implying that a firm's ETR is related to its size. The results indicate that larger firms face higher income tax burdens, thus supporting the political cost theory.

The results indicate that higher levels of debt lead to lower ETRs in Turkey. This suggest that taking on debt is a motivating factor to reduce tax burden for Turkish public listed companies. In contrary to prior researches, the results of this study show a positive and significant relationship between capital intensity and ETRs, which can be explained that capital intensive firms benefit more from other tax policies than deducting the depreciation expenses. Inventory intensity has a positive but insignificant association with ETRs, implying that a firm's ETR is not related to its inventory intensity. The coefficient of ROA is negative and not significant, which is counter to expectations. This controversial result indicates that ROA has no influence over firms' ETRs.

As a robustness check of the results, sensitivity tests are performed. First, variance inflation factors for the independent variables were computed to specify the multicollinearity of the regression model and overall the biggest VIF is not bigger than 1,04. This result indicates that there is no multicollinearity between independent variables. 
To test the relationship between ETRs and explanatory factors, the model was reestimated using alternative measures of ETR, firm size and profitability. First the denominator of ETR is changed to pre-tax income. Instead of ROA, ROE (return on equity) is used as a measure of profitability and firm size is measured as natural logarithm of total sales. In particular, the values of coefficients and significance levels show little changes. The results show that there are no large differences on the coefficients of size, capital intensity. However, the relation between leverage and ETRs is now insignificant and the relation between ETRs and inventory intensity turns significantly positive. The changes may be caused by omitting interest in the denominator by ETR calculation. In literature of accounting, EBIT is viewed as the best measurement of firm revenues.

\section{Conclusion}

In this study it was aimed to investigate the determinants of effective tax rates in Turkey. Based on financial statement information, the effective tax rate of each company was calculated and the results showed that average effective tax rate of Turkish public listed companies is $15 \%$ and under statutory tax rate of $20 \%$. Using panel data estimation procedures, the data show that some of the explanatory variables used in the previous literature have significant effect on the tax burden of Turkish public listed companies. The regression results show that firms size has a significant positive effect on ETR, leverage again significant but negative effect and capital intensity significant positive effect on ETR. The study also found evidence that highly leveraged companies face lower ETRs and highly capitalintensive companies face with higher ETRs.

However, it should be noted that the results are not conclusive, especially for the variables; inventory intensity and profitability. Regarding inventories, the results indicated that there is an insignificant association between inventory intensity and ETRs and it cannot be claimed that more profitable firms are those that pay the most corporate income tax in Turkey.

Effectively, this study confirms the existence of an association between ETRs and firm size, leverage and capital intensity. The study adds to the literature on relationship between ETR and firm specific characteristics in an emerging market. Moreover, the results provide some additional insights into tax burden of listed companies in Turkey, and those are relevant for firm's future decision making. Various groups such as regulatory authorities, who deal with profit shifting and broadness of tax bases, tax researchers, who analyze factors of ETR and impact of tax reforms as well as corporate managers and investors, who use tax-related information for their decisions should also be interested in the results of this study.

The study has several limitations. Because of the data unavailability, it was only possible to include public listed companies in the sample. Adding unlisted companies to the sample would make it easier to assess the relationship between ETR and firm specific characteristics, also to generalize the results. Other factors such as industry specific characteristics, ownership structure, level of family ownership, corporate reorganizations resulting in a merger or acquisition or executives' effects that 
may affect on ETRs can also be included in this study. Further researches should also consider these issues.

\section{References}

Chen, S., Chen, X., Cheng, Q., \& Shevlin, T. (2010). Are family firms more tax aggressive than non-family firms?. Journal of Financial Economics, 95(1), 41-61.

Delgado, F. J., Fernandez-Rodriguez, E., \& Martinez-Arias, A. (2012). Size and other determinants of corporate effective tax rates in US listed companies. International Research Journal of Finance and Economics, 98, 160-165.

Derashid, C., \& Zhang, H. (2003). Effective tax rates and the "industrial policy" hypothesis: evidence from Malaysia. Journal of international accounting, auditing and taxation, 12(1), 45-62.

Feeny, S., Gillman, M., \& Harris, M. N. (2005). Econometric accounting of the Australian corporate tax rates: A firm panel example (No. E2005/16). Cardiff Economics Working Papers.

Fernandez-Rodriguez, E., \& Martinez-Arias, A. (2011). Determinants of effective Tax Rate: Evidence for USA and the EU. Intertax, 39, 381.

Fernández-Rodríguez, E., \& Martínez-Arias, A. (2012). Do Business Characteristics Determine an Effective Tax Rate? Evidence for Listed Companies in China and the United States. Chinese Economy, 45(6), 60-83.

Fernández-Rodríguez, E., \& Martínez-Arias, A. (2014). Determinants of the effective tax rate in the BRIC countries. Emerging Markets Finance and Trade, 50(sup3), 214-228.

Gupta, S., \& Newberry, K. (1997). Determinants of the variability in corporate effective tax rates: Evidence from longitudinal data. Journal of accounting and public policy, 16(1), 1-34.

Harris, M. N., \& Feeny, S. (2003). Habit persistence in effective tax rates. Applied Economics, 35(8), 951-958.

Janssen, B. (2005). Corporate effective tax rates in the Netherlands. De Economist, 153(1), 47-66.

Kim, K. A., \& Limpaphayom, P. (1998). Taxes and firm size in Pacific-Basin emerging economies. Journal of international accounting, auditing and taxation, 7(1), 47-68.

Liu, X., \& Cao, S. (2007). Determinants of corporate effective tax rates: evidence from listed companies in China. Chinese economy, 40(6), 49-67.

Noor, R. M., Mastuki, N. A., \& Bardai, B. (2008). Corporate effective tax rates: A study on Malaysian public listed companies. Malaysian Accounting Review, 7(1).

Noor, R. M., \& Fadzillah, N. S. M. (2010). Corporate tax planning: A study on corporate effective tax rates of Malaysian listed companies. International Journal of Trade, Economics and Finance, 1(2), 189.

Omer, T. C., Molloy, K. H., \& Ziebart, D. A. (1993). An investigation of the firm size-effective tax rate relation in the 1980s. Journal of Accounting, Auditing \& Finance, 8(2), 167-182

Plesko, G. A. (2003). An evaluation of alternative measures of corporate tax rates. Journal of Accounting and Economics, 35(2), 201-226.

Porcano, T. (1986). Corporate tax rates: Progressive, proportional, or regressive. Journal of the American Taxation Association, 7(2), 17-31.

Richardson, G., \& Lanis, R. (2007). Determinants of the variability in corporate effective tax rates and tax reform: Evidence from Australia. Journal of accounting and public policy, 26(6), 689-704.

Shevlin, T. (1987). Taxes and off-balance-sheet financing: research and development limited partnerships. Accounting Review, 480-509. 
Shevlin, T., \& Porter, S. (1992). “ The Corporate Tax Comeback in 1987” Some Further Evidence. The Journal of the American Taxation Association, 14(1), 58.

Stickney, C. P., \& McGee, V. E. (1982). Effective corporate tax rates the effect of size, capital intensity, leverage, and other factors. Journal of accounting and public policy, 1(2), 125-152.

Watts, R., \& Zimmerman, J. (1986). Positive theory of accounting. Englewood Cliffs, NY: Prentice-Hall.

Wilkie, P. J., \& Limberg, S. T. (1993). Measuring explicit tax (dis) advantage for corporate taxpayers: An alternative to average effective tax rates. The Journal of the American Taxation Association, 15(1), 46.

Zimmerman, J. L. (1983). Taxes and firm size. Journal of accounting and economics, 5, 119-149. 